\title{
Effects of Vitamin C and E Administration on Leukocyte Counts in Rainbow Trout (Oncorhynchus mykiss)
}

\begin{abstract}
White blood cells (WBC) or Leukocytes are defense mechanism indicators in fishes. Vitamins $\mathrm{C}$ and $\mathrm{E}$ are among the most important nutrients, providing protection to the leukocytes and subsequently influence the fish health and immune system. This study was conducted to investigate the effects of different levels of vitamins $C$ and $E(0$, 100,200 and $1000 \mathrm{mg} / \mathrm{kg}$ diet) on leukocyte counts of rainbow trout fingerlings during 60 days of feeding trials. The results showed that vitamin $E$ administration increases significantly $(P<0.05)$ the percent of the lymphocytes at 200 and $1000 \mathrm{mg} / \mathrm{kg}$ treatments. In addition, a significant increase $(P<0.05)$ was found in lymphocytes of fish fed with $1000 \mathrm{mg} / \mathrm{kg}$ vitamin C administration. No significant effects of different levels of Vitamins $C$ and $E$ on neutrophils, eosinophils and monocytes were found during the 60 days experiment $(P>0.05)$. The results revealed that administration of Vitamins $C$ and $E$ can be led to a significant increase in lymphocytes that may influence immune response and resistance against disease.
\end{abstract}

Keywords: WBC; Fish; Immune system; Lymphocytes

\section{Introduction}

Nutrition influences the immune system of fishes and plays a crucial role in their health and ability to withstand against diseases [1-3]. In fishes, essential nutrients, including fatty acids, proteins, polysaccharides, vitamins, and some minerals have pivotal importance to reinforce their immune functions [4]. Vitamins C and $\mathrm{E}$ are among the most important nutrients influencing specific and non-specific immune responses of fishes [5-8]. Vitamin $\mathrm{C}$ is an essential micronutrient and water-soluble antioxidant in biological fluids, which is associated to biochemical reactions in cells and tissues. Its deficiency can increase disease susceptibility in fishes affecting their immune system $[9,10]$. In addition, this vitamin has been suggested having a positive role in stress amelioration [11]. Vitamin E is related with immune system function, which acts as an antioxidant in biological membranes. This vitamin can enhance both humoral and cellular defenses, whereas its deficiency can reduce immune responses [12].

Both vitamins may prevent the immunosuppression [13-15], help the inflammatory responses $[14,16,17]$, improve the respiratory burst on the phagocytes $[6,13]$, and enhance the phagocyte activity $[6,8,18]$ and antibody production in fishes [10,19]. Furthermore, they are important antioxidants offering protection against oxidative damages [20], enhancing the resistance of red blood cell membranes [18,21$24]$, protecting leukocyte functions $[5,18,20,25,26]$, and influencing blood cell indices such as leukocytes profile [24,27].

The major functions of the leukocytes are to fight infection, defend the body against foreign organisms in the immune response. It has

\section{Journal of}

Nutrition and Health

Mohammad Rahimi ${ }^{1}$, Sohrab Ahmadivand ${ }^{2}$, Soheil Eagderi $^{3^{*}}$ and Sajjad Shamohammadi ${ }^{4}$

${ }^{\prime}$ Department of Fisheries, khoramshar University of Marian science and technology, Khoramshar, Iran

${ }^{2}$ Department of Aquatic Animal Health, Faculty of Veterinary Medicine, University of Tehran, Tehran, Iran

${ }^{3}$ Department of Fisheries, Faculty of Natural Resources, University of Tehran, Karaj, Iran

${ }^{4}$ Karaj Payam Noor University, Karaj, Iran

*Address for Correspondence

Soheil Eagderi, Department of Fisheries, Faculty of Natural Resources, University of Tehran, Karaj, Iran, E-mail: soheil.eagderi@ut.ac.ir

Submission: 07 September, 2015

Accepted: 08 December, 2015

Published: 14 December, 2015

Copyright: ( 2015 Rahimi M, et al. This is an open access article distributed under the Creative Commons Attribution License, which permits unrestricted use, distribution, and reproduction in any medium, provided the original work is properly cited.

Reviewed \& Approved by: Dr. Abdelmonem S. Hassan, Associate Professor of Nutritional Sciences, College of Arts \& Science, University of Qatar, Qatar

been shown that natural and exogenous stressors in the environment elicit a stress response in fish leukocyte counts, suggesting leukocyte counts can be considered as a novel marker of immunotoxicity [28-30]. Therefore, hematologic evaluation, especially leukocyte counts can be useful in monitoring of fish health and its immune response, due to the influence of intrinsic and extrinsic factors on the appearance of cells and its quantitative values [31]. Hence, this study was conducted to investigate the effects of different levels of vitamin $\mathrm{C}$ and $\mathrm{E}$ (i.e. each of $0,100,200$ and $1000 \mathrm{mg} / \mathrm{kg}$ diet) on leukocyte counts of rainbow trout (Oncorhynchus mykiss) during 60 days of experiments.

\section{Materials and Methods}

\section{Experimental design, procedures and diets}

The experiment was conducted for a period of 60 days in Tehran Ghezel Ala Co. (Firoozkooh city, northern Iran). Eight experimental diets with similar energy and protein levels containing different levels of the vitamin E (i.e. 0.0, 100, 200, $1000 \mathrm{mg} / \mathrm{kg}$ diet) and Vitamin C (i.e. $0.0,100,200,1000 \mathrm{mg} / \mathrm{kg}$ diet) was selected as treatments and evaluated. The rainbow trout fingerlings (as three replicates of eight treatments) with mean initial weight of $2.1 \pm 0.15 \mathrm{~g}$ were introduced into twenty-four $100 \mathrm{~L}$ tanks, each containing 50 fish. During the experiment, the water flow rate, $\mathrm{pH}$, average dissolved oxygen and water temperature were $0.5 \mathrm{~L} / \mathrm{S}, 7.8,8.5 \mathrm{ppm}$ and $10-13^{\circ} \mathrm{C}$, respectively, with a natural photoperiod (10 L: $14 \mathrm{D})$.

Formulations and proximate composition of the experimental diets are presented in Table1. Briefly, the dietary ingredients were thoroughly mixed, made into pellets and air-dried at room temperature. The pellets were ground and sieved into small size and 
Citation: Rahimi M, Ahmadivand S, Eagderi S, Shamohammadi S. Effects of Vitamin C and E Administration on Leukocyte Counts in Rainbow Trout (Oncorhynchus mykiss). J Nutri Health. 2015;1(2): 5.

ISSN: 2469-4185

Table1: Composition of the experimental diet (dry weight).

\begin{tabular}{|l|l|}
\hline Ingredient & Amount (\%) \\
\hline Fish meal & 58 \\
\hline Wheat flour & 14 \\
\hline Meat flour & 12 \\
\hline Dextrin & 5 \\
\hline Fish oil & 6 \\
\hline Vegetable Oil & 2.2 \\
\hline Filler (sawdust) & 0.8 \\
\hline Mineral mixture ${ }^{1}$ & 1 \\
\hline Vitamin mixture (vitamin E or C free) ${ }^{2}$ & 1 \\
\hline Proximate composition (\%) & \\
\hline Moisture & $10 \pm 0.8$ \\
\hline Crude protein & $49 \pm 1$ \\
\hline Crude lipid & $15.1 \pm 0.8$ \\
\hline Ash & $11.5 \pm 0.92$ \\
\hline Energy(Kcal/gr) & 380 \\
\hline
\end{tabular}

${ }^{1}$ One kilogram mineral premix contained $130.6 \mathrm{~g}$ calcium phosphate dibasic $327 \mathrm{~g}$ calcium lactate, $29.7 \mathrm{~g}$ ferric citrate, $137 \mathrm{~g}$ magnesium sulfate, $239.8 \mathrm{~g}$ potassium phosphate dibasic, $87.2 \mathrm{~g}$ sodium phosphate dibasic, $43.5 \mathrm{~g}$ sodium chloride; $0.15 \mathrm{~g}$, aluminum chloride hexahydrate, $0.15 \mathrm{~g}$ potassium iodine, 0.1 $\mathrm{g}$ cupric chloride, $0.8 \mathrm{~g}$ manganese sulfate monohydrate, $1 \mathrm{~g}$ cobalt chloride hexahydrate, and $3 \mathrm{~g}$ zinc sulfate heptahydrate.

${ }^{2}$ Vitamin mixture was manually provided according to feed requirements of the fish and ingredients were obtained from Science Laboratories (Ghazvin, Iran); which provides $6600 \mathrm{IU}$ vitamin A (retinol palmitate), $2400 \mathrm{IU}$ vitamin D3, $28 \mathrm{mg}$ vitamin $\mathrm{K}$ (menadione sodium bisulfate), $47 \mathrm{mg}$ thiamin, $53 \mathrm{mg}$ riboflavin, $38 \mathrm{mg}$ pyridoxine, $115 \mathrm{mg}$ pantothenate, $220 \mathrm{mg}$ niacin, $0.6 \mathrm{mg}$ biotin, $12.7 \mathrm{mg}$ folic acid, $0.06 \mathrm{mg}$ vitamin $\mathrm{B} 12$, and $300 \mathrm{mg}$ inositol per $\mathrm{kg}$ feed. The diets of vitamin $\mathrm{E}$ and $C$ controls supplemented with $100 \mathrm{mg} / \mathrm{kg}$ diet vitamin $C$ and $E$, respectively. Vitamin $\mathrm{E}$ and $\mathrm{C}$ used in the diets were DI-all-rac- $\alpha$-tocopherol and L (+)-Ascorbic acid calcium salt dihydrate, (Sigma, USA).

stored at $4{ }^{\circ} \mathrm{C}$ until were used to feed fish. The fingerlings were fed at $3-5 \%$ of body weight five times a day $(8,11,13,15$, and $18 \mathrm{hrs})$. Diet compositions were analyzed based on AOAC [32].

\section{Hematological assay}

At the end of the experiment, 15 fish were sampled from each treatment and anesthetized immediately by clove oil solution (100 mg $\left.\mathrm{L}^{-1}\right)$. Then, the blood samples were taken from the caudal vasculature using a heparinized syringe and transferred to a $2 \mathrm{ml}$ heparinized tube. Differential leukocyte counts were performed as the percent of the lymphocyte, neutrophil, eosinophil and monocyte after preparing the smear and staining. The smears were air-dried, fixed in $96 \%$ ethanol for 30 minutes and stained with Giemsa for 30 minutes. The smears were considered for leukocyte differential count under a compound microscope based on Klontz [33].

\section{Statistical analysis}

Data was tested for normality using Kolmogorov-Smirnov test. All data were normally distributed. Data was analyzed using one-way ANOVA by SPSS 20.0 statistical software. The data was compared using Duncan's test at a significance level of 5\%. Data is expressed as means \pm S.E.M.

\section{Results}

The results of the leukocyte differential counts were summarized in Figures 1 (A-D) and 2 (A-D). After 60 days, vitamin E administration showed a significant increase $(\mathrm{P}<0.05)$ in the percent of lymphocytes in treatment $200 \mathrm{mg} / \mathrm{kg}(85.3 \pm 4.1 \%)$ and $1000 \mathrm{mg} / \mathrm{kg}(83.3 \pm 6.6 \%)$ compared to that of the control group (76 $\pm 4.3 \%)$ (Figure 1B). The results showed no significant effect of different administrated dose of the vitamin $\mathrm{E}$ on neutrophils, monocytes, and eosinophils (Figures $1 \mathrm{~A}, 1 \mathrm{C}$ and $1 \mathrm{D}$, respectively) after 60 day experiment period $(\mathrm{P}>0.05)$.

A significant increase $(\mathrm{P}<0.05)$ was found in lymphocytes $(86$ $\pm 5.4 \%$ in $1000 \mathrm{mg} / \mathrm{kg}$ treatment of vitamin C administration, whereas no significant changes were observed in the other treatment (Figure 2B). The mean values of lymphocytes in the 0,100 , and 200 $\mathrm{mg} / \mathrm{kg}$ vitamin $\mathrm{C}$ treatments were $76 \pm 3.4,77 \pm 1.4$, and $80.6 \pm 2.3$, respectively. The results showed no significant effect of different administrated dose of the vitamin $\mathrm{C}$ on neutrophils, monocytes, and eosinophils (Figures 1A, 1C and 1D, respectively) after 60 day experiment period $(\mathrm{P}>0.05)$.

\section{Discussion}

Aquaculture is one of the fastest growing animal production sectors in the world, which has constraint due to emerging of disease outbreaks [34]. There is a rapidly increasing literature pointing to the success of probiotics, vitamins, plant products and immunostimulants, in immune modulation, namely stimulation of the adaptive and innate immune response, and the control of fish diseases $[35,36]$. The dietary supplements of vitamins have promised reducing the severity of disease, and enhancing of immune response $[35,36]$. Leukocytes are defense mechanism indicators in fishes, and it has shown that vitamins $\mathrm{E}$ and $\mathrm{C}$ are potent antioxidants that can provide the protection to the leukocyte function $[5,18,25,26]$. The vitamin $\mathrm{E}$ and/or $\mathrm{C}$ supplementation in the diet of fishes has shown a greater efficiency in the production of antibodies, lysozyme levels, phagocyte activity and stress attenuation $[6,14]$.

In the present study, the administration of high levels of Vitamin $\mathrm{C}$ and $\mathrm{E}$ showed a significant increase in lymphocytes. Although, there are some literatures regarding the application of the dietary Vitamin $\mathrm{C}$ and/or E on fishes with immunological assay, but there are no enough results regarding their effects on leukocyte counts. Safarpour-Amlashi et al. reported higher lymphocytes in Beluga (Huso huso) fed with the high levels of vitamin E ( $400 \mathrm{mg} / \mathrm{kg}$ diet) for 8 weeks [37]. It has also shown a significant increase of lymphocytes in fish fed vitamin C at an elevated dose for longer periods $[20,38]$. In contrast to our findings, Menezes et al. pointed out that vitamin $\mathrm{E}$ supplemented in fish diet reduces the number of total thrombocytes, lymphocytes and neutrophils, and increases eosinophils [39]. They also reported that vitamin $\mathrm{C}+\mathrm{E}$ and $\mathrm{C}$ increase total leukocytes, thrombocytes and eosinophils in pirarucu (Arapaima gigas). It can be suggested that differences in fish species and environmental factors are related to different results.

Lymphocytes are responsible for the production of antibodies in fishes, and may be affected by an alteration in their membrane stability, which can be influenced by these vitamins. It has been found that feeding with vitamin $\mathrm{E}$ deficient diets decreases the function of $\mathrm{T}$ and $\mathrm{B}$-lymphocytes in rainbow trout sensitized against Yersinia 
Citation: Rahimi M, Ahmadivand S, Eagderi S, Shamohammadi S. Effects of Vitamin C and E Administration on Leukocyte Counts in Rainbow Trout (Oncorhynchus mykiss). J Nutri Health. 2015;1(2): 5.
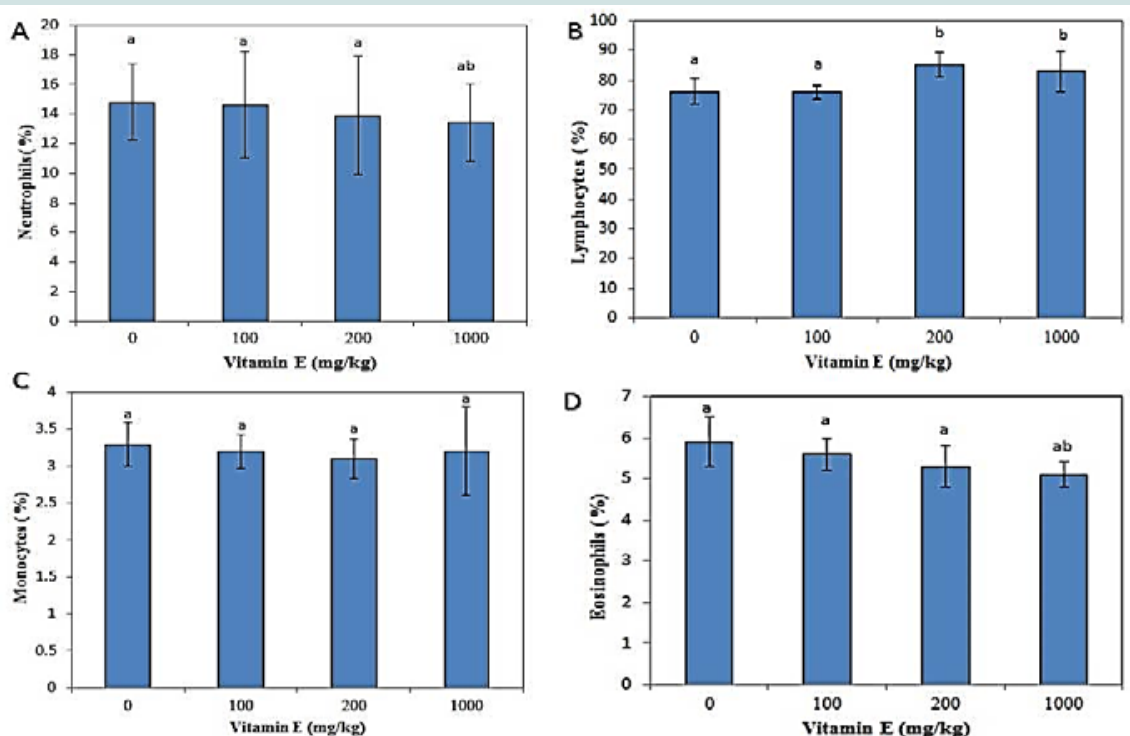

Figure 1: Leukocyte differential count ((a) neutrophils, (b) lymphocytes, (c) monocytes and (d) eosinophils) in rainbow trout fingerlings fed with different levels of vitamin E. Data is shown as means \pm SEM $(n=15)$. Different letters indicate significant differences between the treatment and control groups at $P<0.05$.
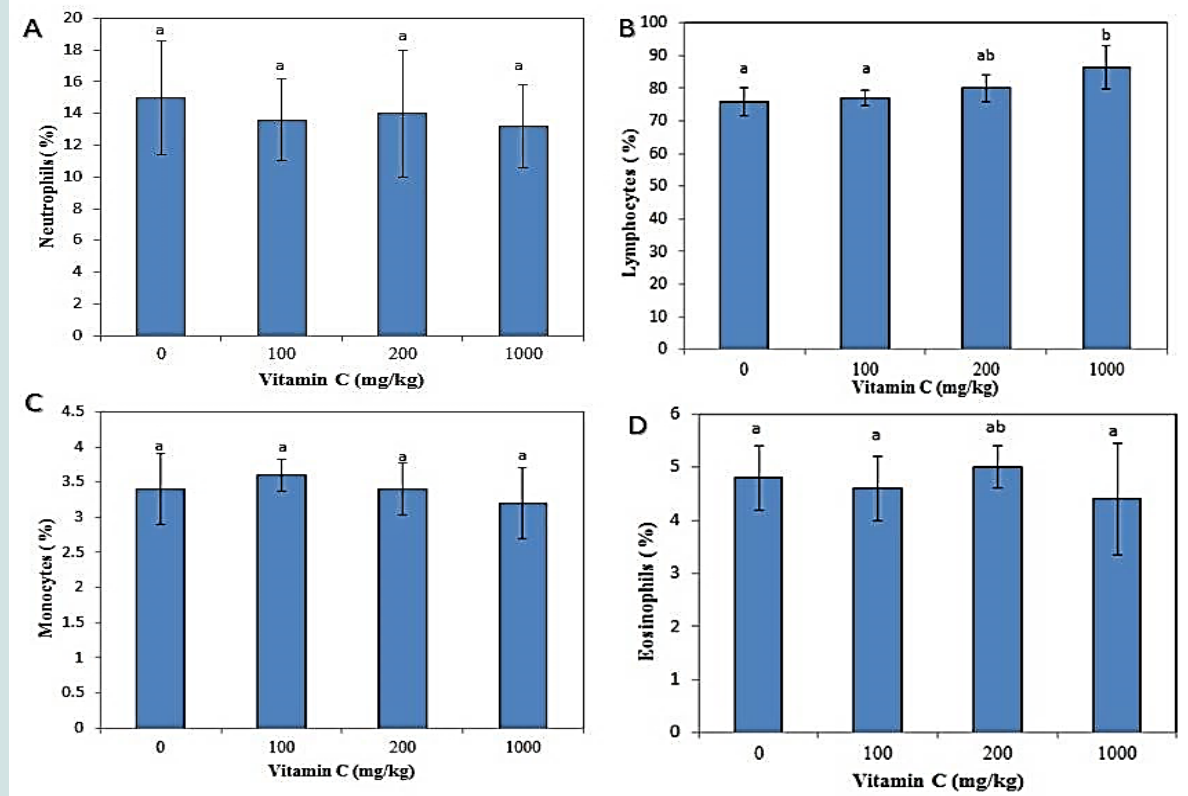

Figure 2: Leukocyte differential count ((a) neutrophils, (b) lymphocytes, (c) monocytes and (d) eosinophils) in rainbow trout fingerlings fed with different levels of vitamin C. Data is shown as means \pm SEM $(n=15)$. Different letters indicate significant differences between the treatment and control groups at $P<0.05$.

ruckeri [40]. It has also shown that vitamin C enhances antibody production against Vibrio anguillarum in rainbow trout [41] and against Edwarsiella ictaluri in channel catfish [9]. Therefore, antibody production may be influenced as a result of observed change in lymphocytes value; however, it needs to be evaluated.

Vitamins C and E provide cellular defense against the uncontrolled generation of reactive oxygen species (ROS) from normal aerobic metabolism, and by oxidative challenges such as pollution, infection, tissue damage and oxidative drug, which can damage biological membranes and DNA [42]. Furthermore, It has been confirmed that oxidation of leukocytes membrane lipids can change the synthesis of some complement proteins and consequently their functions [43]. Hence, alterations in leukocyte membrane due to different intakes of vitamin $\mathrm{E}$ and $\mathrm{C}$, and also function of these vitamins trough ROS pathway maybe modulate the complement activity and enhance immunity in fish.

In conclusion, our findings suggest the effects of diets with 
Citation: Rahimi M, Ahmadivand S, Eagderi S, Shamohammadi S. Effects of Vitamin C and E Administration on Leukocyte Counts in Rainbow Trout (Oncorhynchus mykiss). J Nutri Health. 2015;1(2): 5.

sufficient Vitamin $\mathrm{E}$ and $\mathrm{C}$ on leukocytes in rainbow trout fingerlings, which may influence disease resistance and immune response. Further research is necessary to evaluate the antibody production and complement activity. Furthermore, the mechanisms by which the high dose of vitamin $\mathrm{E}$ and $\mathrm{C}$ influences lymphocytes is unclear, which require further investigation as well.

\section{References}

1. Landolt ML (1989) The relationship between diet and the immune response of fish. Aquaculture 79: 193-206.

2. Blazer VS (1992) Nutrition and disease resistance in fish. Annu Rev Fish Dis 2: 309-323.

3. Lall SP, Olivier G (1993) Role of micronutrients in immune response and disease resistance in fish. In: INRA (Ed.). Fish Nutrition in Practice Les Colloques 61: 101-118

4. Barrows FT, Gaylord TG, Sealey WM, Porter L, Smith CE (2008) The effect of vitamin premix in extruded plant-based and fish meal based diets on growth efficiency and health of rainbow trout, Oncorhynchus mykiss. Aquaculture 283: $148-155$.

5. Wahli T, Verlhac V, Gabaudan J, Schuep W, Meier W (1998) Influence of combined vitamins $C$ and $E$ on non-specific immunity and disease resistance of rainbow trout, Oncorhynchus mykiss (Walbaum). J Fish Dis 21: 127-137.

6. $\square \square$ Ortuño J, Esteban MA, Meseguer J (2003) The effect of dietary intake of vitamins $C$ and $E$ on the stress response of gilthead seabream (Sparus aurata L.). Fish Shellfish Immunol 14: 145-156.

7. Shiau SY, Hsu CY (2002) Vitamin E sparing effect by dietary vitamin C in juvenile hybrid tilapia, Oreochromis niloticus $\times$ O. aureus. Aquaculture 210 : $335-342$

8. Puangkaew J, Kiron V, Somamoto T, Okamoto N, Satoh S, et al. (2004) Nonspecific immune response of rainbow trout (Oncorhynchus mykiss Walbaum) in relation to different status of vitamin $\mathrm{E}$ and highly unsaturated fatty acids. Fish Shellfish Immunol 16: 25-39.

9. Li Y, Lovell RT (1985) Elevated levels of dietary ascorbic acid increase immune responses in channel catfish. J Nutr 115: 123-131.

10. Hardie LJ, Fletcher TC, Secombes CJ (1991) The effect of dietary vitamin C on the immune responses of the Atlantic salmon (Salmo salar L.). Aquaculture 95: 201-214.

11. Fletcher TC (1997) Dietary effects on stress and health. In: Iwama GK, Pickering AD, Sumpter JP, Schreck CB (Eds.), Fish Stress and Health in Aquaculture. Cambridge University Press, Cambridge, Newyork, pp. 223246

12. Hardie LJ, Fletcher TC, Secombes CJ (1990) The effect of vitamin E on the immune responses of the Atlantic salmon (Salmo salar L.). Aquaculture 87: $1-13$.

13. Waagbo R (1994) The impact of nutritional factors on the immune system in Atlantic salmon, Salmo salar L.: a review. Aquac Res 25: 175-197.

14. Montero D, Marrero M, Izquierdo MS, Robaina L, Vergara JM, et al. (1999) Effect of vitamin $\mathrm{E}$ and $\mathrm{C}$ dietary supplementation on some immune parameters of gilthead seabream (Sparus aurata) juveniles subjected to crowding stress. Aquaculture 171: 269-278.

15. Belo MA, Schalch SH, Moraes FR, Soares VE, Otoboni AM, et al. (2005) Effect of dietary supplementation with vitamin $\mathrm{E}$ and stocking density on macrophage recruitment and giant cell formation in the teleost fish (Piaractus mesopotamicus). J Comp Pathol 133: 146-154.

16. Petric MC, Martins ML, Onaka EM, Moraes JRE, Moraes FR, et al. (2003) Suplementação alimentar com vitamina C potencializa a formação de macrófagos policariontes em Piaractus mesopotamicus Holmberg, 1887 (Osteichthyes: Characidae). Bol Inst Pesca 29: 69-76.

17. Reno F, Aina V, Gatti S, Cannas M (2005) Effect of vitamin E addition to poly( $\mathrm{D}, \mathrm{L})$-lactic acid $\mathrm{n}$ surface properties and osteoblast behaviour.
Biomaterials 26: 5594-5599.

18. Sahoo PK, Mukherjee SC (2002) Influence of high dietary a-tocopherol acetate intakes on specific immune response, nonspecific resistance factors and disease resistance of healthy and aflatoxin B1-induced immunocompromised Indian major carp, Labeo rohita (Hamilton). Aquac Nutr 8: 159-167.

19. Ndoye A, Ghanmi Z, Koenig J, Deshaux, P (1990) Vitamin E et immunite': effets dela vitamine $\mathrm{E}$ sur la production d'anticorps anto Yersinia ruckeri chez la truite arc-en-ciel (Salmo gairdneri). Ichtyophysiol Acta 13: 17-23.

20. Adham KG, Hashem HO, Abu-Shabana MB, Kamel AH (2000) $\square \square$ Vitamin C deficiency in the catfish (Clarias gariepinus). Aquac Nutr 6: 129-139.

21. Pearce J, Harris JE, Davies SJ (2003) The effect of vitamin E on the serum complement activity of the rainbow trout, Oncorhynchus mykiss (Walbaum). Aquac Nutr 9: 337-340.

22. Sau SK, Paul BN, Mohanta KN, Mohanty SN (2004) Dietary vitamin E requirement, fish performance and carcass composition of rohu (Labeo rohita) fry. Aquaculture 240: 359-368.

23. Kiron V, Puangkaew J, Ishizaka K, Satoh S, Watanabe T (2004) Antioxidant status and nonspecific immune responses in rainbow trout (Oncorhynchus mykiss) fed two levels of vitamin E along with three lipid sources. Aquaculture 234: 361-379.

24. Chen R, Lochmann R, Goodwin A, Praveen K, Dabrowski K, et al. (2004) Effects of dietary vitamins $\mathrm{C}$ and $\mathrm{E}$ on alternative complement activity, hematology, tissue composition, vitamin concentrations and response to heat stress in juvenile golden shiner (Notemigonus crysoleucas). Aquaculture 242: 553-569.

25. Verlhac V, Gabaudan J, Obach A, Schüep W, Hole R (1996) Influence of dietary glucan and vitamin $C$ on non-specific and specific response of rainbow trout, Oncorhynchus mykiss. Aquaculture 143: 123-133.

26. Cuesta A, Esteban MA, Meseguer J (2002) Natural cytotoxic activity in seabream (Sparus aurata L.) and its modulation by vitamin C. Fish Shellfish Immunol 13: 97-109.

27. Pimpimol T, Phoonsamran K, Chitmanat C (2012) Effect of dietary vitamin C supplementation on the blood parameters of mekong giant catfish (Pangasianodon gigas). Int J Agric Biol 14: 256-260.

28. Milla S, Depiereux S, Kestemont $P$ (2011) The effects of estrogenic and androgenic endocrine disruptors on the immune system of fish: a review. Ecotoxicology 20: 305-319.

29. Ahmadivand S, Farahmand H, Mirvaghefi A, Eagderi S, Zargar A (2015) Effects of (Anti) androgenic endocrine disruptors (DEHP and Butachlor) on Immunoglobulin $\mathrm{M}$ (IgM) and leukocytes counts of male rainbow trout (Oncorhynchus mykiss). Bull Environ Contam Toxicol 94: 695-700.

30. Davis, AK, Maney DL, Maerz JC (2008) The use of leukocyte profiles to measure stress in vertebrates: a review for ecologists. Funct Ecol 22: 760772.

31. Clauss TM, Dove AD, Arnold JE (2008) Hematologic disorders of fish. Vet Clin North Am Exot Anim Pract 11: 445-462.

32. AOAC (1990) In: Helrich K, (Ed.). Official methods of analysis of the association of official analytical chemists, (15th edn). Association of Official Analytical Chemists Inc USA, pp. 1-30.

33. Klontz GW (1994) Fish hematology. In: Stolen JS, Fletcher TC, Rowley AF, Kelikoff TC, Kaattari SL, et al. (Eds.), Techniques in fish immunology. SOS Publications 3: 121-132.

34. Subasinghe RP, Curry D, McGladdery SE, Bartley D (2003) Recent technological innovations in aquaculture. In: Review of the State of World Aquaculture. FAO Fisheries Circular, pp. 59-74

35. Riquelme C, Araya R, Vergra N, Rojas A, Guaita M, et al. (1997) Potential probiotic strain in the culture of Chilean scallop Argopecten purpuratus (Lamark 1819). Aquaculture 154: 17-26.

36. Newaj-Fyzul1 A, Austin B (2014) Probiotics, immunostimulants, plant products and oral vaccines, and their role as feed supplements in the control of bacterial fish diseases. J Fish Dis 38: 937-955. 
Citation: Rahimi M, Ahmadivand S, Eagderi S, Shamohammadi S. Effects of Vitamin C and E Administration on Leukocyte Counts in Rainbow Trout (Oncorhynchus mykiss). J Nutri Health. 2015;1(2): 5.

ISSN: 2469-4185

37. Amlashi AS, Falahatkar B, Sattari M, Gilani MH (2011) Effect of dietary vitamin $\mathrm{E}$ on growth, muscle composition, hematological and immunological parameters of sub-yearling beluga Huso huso L. Fish Shellfish Immunol 30 807-814

38. Verlhac V, Gabaudan J (1994) Influence of vitamin C on the immune system of salmonids. Aquac Res 25: 21-36.

39. De Menezes GC, Tavares-Dias M, Ono EA, de Andrade JI, Brasil EM, et al. (2006) The influence of dietary vitamin $C$ and $E$ supplementation on the physiological response of pirarucu, Arapaima gigas, in net culture. Comp Biochem Physiol A Mol Integr Physiol 145: 274-279.

40. Blazer VS, Wolke RE (1984) The effects of a-tocopherol on the immune response and nonspecific resistance factors of rainbow trout (Salmo gairdneri Richardson). Aquaculture 37: 1-9

41. Navarre O, Halver JE (1989) Disease resistance and humoral antibody production in rainbow trout fed high levels of vitamin C. Aquaculture 79: 207221

42. Halliwell B, Gutteridge JM (1990) The antioxidants of human extracellular fluids. Arch Biochem Biophys 180: 1-8.

43. Obach A, Quentel C, Laurencin FB (1993) Effects of alpha-tocopherol and dietary oxidized fish-oil on the immune-response of Sea Bass Dicentrarchus labrax. Dis Aquat Org 15: 175-185. 